\title{
No association between TGF-beta 1 polymorphisms and radiation-induced lung toxicity in a European cohort of lung cancer patients
}

Citation for published version (APA):

Voets, A. M., Oberije, C., Struijk, R. B., Reymen, B., De Ruyck, K., Thierens, H., Vandecasteele, K., De Neve, W., Houben, R., De Ruysscher, D., Smeets, H. J. M., \& Lambin, P. (2012). No association between TGF-beta 1 polymorphisms and radiation-induced lung toxicity in a European cohort of lung cancer patients. Radiotherapy and Oncology, 105(3), 296-298. https://doi.org/10.1016/j.radonc.2012.09.016

Document status and date:

Published: 01/12/2012

DOI:

10.1016/j.radonc.2012.09.016

Document Version:

Publisher's PDF, also known as Version of record

Document license:

Taverne

Please check the document version of this publication:

- A submitted manuscript is the version of the article upon submission and before peer-review. There can be important differences between the submitted version and the official published version of record.

People interested in the research are advised to contact the author for the final version of the publication, or visit the DOI to the publisher's website.

- The final author version and the galley proof are versions of the publication after peer review.

- The final published version features the final layout of the paper including the volume, issue and page numbers.

Link to publication

\footnotetext{
General rights rights.

- You may freely distribute the URL identifying the publication in the public portal. please follow below link for the End User Agreement:

www.umlib.nl/taverne-license

Take down policy

If you believe that this document breaches copyright please contact us at:

repository@maastrichtuniversity.nl

providing details and we will investigate your claim.
}

Copyright and moral rights for the publications made accessible in the public portal are retained by the authors and/or other copyright owners and it is a condition of accessing publications that users recognise and abide by the legal requirements associated with these

- Users may download and print one copy of any publication from the public portal for the purpose of private study or research.

- You may not further distribute the material or use it for any profit-making activity or commercial gain

If the publication is distributed under the terms of Article $25 \mathrm{fa}$ of the Dutch Copyright Act, indicated by the "Taverne" license above, 
Clinical radiogenomics

\title{
No association between TGF- $\beta 1$ polymorphisms and radiation-induced lung toxicity in a European cohort of lung cancer patients
}

\author{
An M. Voets ${ }^{a}$, Cary Oberije ${ }^{a}$, Robin B. Struijk ${ }^{a}$, Bart Reymen ${ }^{a}$, Kim De Ruyck ${ }^{b}$, Hubert Thierens ${ }^{b}$, \\ Katrien Vandecasteele ${ }^{c}$, Wilfried De Neve ${ }^{c}$, Ruud Houben ${ }^{a}$, Dirk De Ruysscher ${ }^{a}$, Hubert J.M. Smeets ${ }^{a}$, \\ Philippe Lambin ${ }^{\mathrm{a}, *}$ \\ ${ }^{\mathrm{a}}$ Maastricht University, The Netherlands; ${ }^{\mathrm{b}}$ Ghent University; and ${ }^{\mathrm{c}}$ Ghent University Hospital, Belgium
}

\section{A R T I C L E I N F O}

\section{Article history:}

Received 3 July 2012

Received in revised form 14 September

2012

Accepted 15 September 2012

Available online 3 November 2012

\section{Keywords:}

Lung cancer

Radiotherapy

Dyspnea

TGF- $\beta 1$

Polymorphisms

\begin{abstract}
A B S T R A C T
This study aimed at validating the previously published association between TGF- $\beta 1$ single nucleotide polymorphisms and a reduced risk for radiation-induced lung toxicity. We were not able to confirm the reported association, neither using maximum dyspnea score nor after correction for baseline dyspnea score.

(c) 2012 Elsevier Ireland Ltd. All rights reserved. Radiotherapy and Oncology 105 (2012) 296-298
\end{abstract}

Radiation-induced lung toxicity (RILT) is a dose-limiting factor for radiotherapy [1]. Because current parameters are only moderately associated with RILT, there is a demand for novel parameters [2-4]. Yuan et al. [5] and Wang and Bi [6] have studied previously the association between TGF- $\beta 1$ single nucleotide polymorphisms (SNPs; rs1800469:C-509T, rs1800470:T869C and rs1800471: G915C) and the risk of developing radiation-induced pneumonitis (RP) in patients with non-small-cell lung cancer (NSCLC). Yuan et al. showed an association between the CT/CC genotypes of rs1982073:T869C (new SNP ID rs1800470) and a lower RP risk (hazard ratio 0.489 for grade $\geqslant 2$ and 0.390 for grade $\geqslant 3$ ) in 164 patients of mixed ethnicity with TGF- $\beta 1$ genotype distributions similar to Caucasian patients in general [5]. Wang and Bi could not confirm an association for the same three SNPs in a Chinese cohort $(n=178)$ and also did not find a correlation between any of the TGF- $\beta 1$ SNPs and TGF- $\beta 1$ levels in the blood [6]. The authors suggested that differences in genetic backgrounds between people of Caucasian and Chinese descent could partly explain the contradictory results.

\footnotetext{
* Corresponding author. Address: Maastricht Radiation Oncology (MAASTRO), Maastricht University, P.O. Box 616, 6200 MD Maastricht, The Netherlands.

E-mail address: philippe.lambin@maastro.nl (P. Lambin).
}

Therefore, we genotyped the same three TGF- $\beta 1$ SNPs in a European cohort of lung cancer patients.

\section{Material and methods}

Patient population

The patient population $(n=209)$ is described in Table 1 . Patients were recruited from MAASTRO Clinic $(n=162)$ and the Ghent University Hospital $(n=47)$. All the treatments were controlled with in vivo dosimetry [7]. Lung toxicity was scored using the Common Terminology Criteria for Adverse Events version 3.0 for dyspnea before (baseline) and up to 1 year after (maximum) radiotherapy. The study was approved by the ethics committees of both centers, and all study participants provided written informed consent.

\section{Genotyping}

The TGF- $\beta 1$ SNPs were genotyped using PCR and Sanger sequencing. The target fragments were amplified using primers 5'-GTC GCA GGG TGT TGA GTG ACA G-3' and 5'-GGA CCA GGC GGA GAA GGC TTA-3' for rs1800469 and 5'-ACC ACT GCG CCC TTC TCC CT-3' and 5'-GCG CTT CCG CTT CAC CAG CT-3' for rs1800470 + rs1800471 according to the following program: $95{ }^{\circ} \mathrm{C}$ for $5 \mathrm{~min}$, followed by 35 cycles of $95^{\circ} \mathrm{C}$ for $30 \mathrm{~s}, 58^{\circ} \mathrm{C}$ for 
Table 1

Patient characteristics $(N=209)$.

\begin{tabular}{|c|c|c|c|}
\hline Variable & No. & & $\%$ \\
\hline \multicolumn{4}{|l|}{ Sex } \\
\hline Male & 150 & & 71.8 \\
\hline Female & 59 & & 28.2 \\
\hline \multicolumn{4}{|l|}{ Age, years } \\
\hline Median & & 66 & \\
\hline Range & & $42-87$ & \\
\hline \multicolumn{4}{|l|}{ Smoking status } \\
\hline No smoker & 7 & & 3.3 \\
\hline Former smoker & 128 & & 61.2 \\
\hline Current smoker & 69 & & 33.0 \\
\hline Unknown & 5 & & \\
\hline \multicolumn{4}{|l|}{ Histopathology } \\
\hline NSCLC, NOS & 149 & & 71.3 \\
\hline SCLC & 52 & & 24.9 \\
\hline $\mathrm{NSCLC}+\mathrm{SCLC}$ & 1 & & 0.5 \\
\hline Unknown & 7 & & \\
\hline \multicolumn{4}{|l|}{ Tumor stage } \\
\hline I & 26 & & 12.4 \\
\hline II & 22 & & 10.5 \\
\hline IIIa & 72 & & 34.4 \\
\hline IIIb & 72 & & 34.4 \\
\hline IV & 5 & & 2.4 \\
\hline Unknown & 12 & & \\
\hline \multicolumn{4}{|l|}{ Treatment } \\
\hline Sequential chemoradiation & 58 & & 27.8 \\
\hline Concurrent chemoradiation & 108 & & 51.7 \\
\hline Radiation alone & 42 & & 19.6 \\
\hline Unknown & 1 & & \\
\hline \multicolumn{4}{|l|}{ Radiation dose $(n=209), G y$} \\
\hline Median & & 60.0 & \\
\hline Range & & $40-79.2$ & \\
\hline \multicolumn{4}{|l|}{ Mean lung dose $(n=186)$, Gy } \\
\hline Median & & 14.4 & \\
\hline Range & & $2.6-23.4$ & \\
\hline \multicolumn{4}{|l|}{$V_{20}(n=108), \%$} \\
\hline Median & & 23.4 & \\
\hline Range & & $0-54$ & \\
\hline \multicolumn{4}{|l|}{ Pre-RT FEV $1.0(n=133), L$} \\
\hline Median & & 2.1 & \\
\hline Range & & $0.6-3.9$ & \\
\hline \multicolumn{4}{|l|}{ Baseline dyspnea score } \\
\hline 0 & 110 & & 52.6 \\
\hline 1 & 68 & & 32.5 \\
\hline 2 & 27 & & 12.9 \\
\hline 3 & 4 & & 1.9 \\
\hline
\end{tabular}

Abbreviations: NSCLC, non-small-cell lung cancer; SCLC, small-cell-lung cancer; NOS, not otherwise specified; $V_{20}$, volume of normal lung receiving $20 \mathrm{~Gy}$ or more radiation; FEV 1.0, forced expiratory volume in $1 \mathrm{~s}$.

$45 \mathrm{~s}, 72{ }^{\circ} \mathrm{C}$ for $1 \mathrm{~min}$, and a final extension step at $72{ }^{\circ} \mathrm{C}$ for $10 \mathrm{~min}$. After evaluation in agarose gel, the PCR products were cleaned-up using a QIAquick PCR Purification Kit (QIAGEN). Then, the purified DNA is sequenced using a BigDye Terminator v1.1 Cycle Sequencing Kit (Applied Biosystems) and analyzed on a ABI3730 (Applied Biosystems) using the software program Sequencing Analysis 5.2 (Results in Supplementary Table). Genotypes were scored by two independent researchers, blinded for the dyspnea scores. Only sequences with high software quality scores (trace score $>20,<1 \%$ probability of error) and clear homozygous or heterozygous calls were included.

\section{Statistical analysis}

To test for significant correlations between genotypes (three separate or two combined versus the other) and maximum dyspnea score or delta dyspnea score, chi square tests were used with SPSS software. To check if dosimetric parameters were unevenly distributed between genotypes, we performed $T$ tests and ANOVA.

\section{Results}

The values for radiation dose, mean lung dose and $V_{20}$ of the patient population compare well with the Chinese study [6], whereas the mean lung dose and $V_{20}$ were lower compared with the study by Yuan et al. [5]. A power calculation showed that we are able to detect differences in prevalence between genotypes of a magnitude of 15-20 percent points with this population of 209 patients (power 0.80; alpha 0.05; assuming equal division across subgroups) which is of the same magnitude as Yuan and colleagues [5]. Furthermore, our follow-up time of up to one year was similar to the 10 months follow-up by Yuan et al. for the reported significant hazard ratios. We failed to validate that any of the three TGF$\beta 1$ SNPs were associated with increased lung toxicity when using the patients' maximum dyspnea score (Table 2).

In addition to classifying the patients according to the maximum dyspnea score they developed after radiotherapy, we performed another analysis taking into account the dyspnea score of the patients before radiotherapy (delta dyspnea = maximum dyspnea - baseline dyspnea) to correct for lung disease before radiotherapy [1]. A similar approach, quantifying changes in regional perfusion between pre- and post-radiation, has recently been used by others [8]. Again we could not find an association between any of the three TGF- $\beta 1$ SNPs and delta dyspnea score (Table 2). Statistical tests for differences in dosimetric parameters between genotypes were not significant.

Although we cannot exclude smaller differences than those which are detectable with the current population size, we certainly did not detect a large effect as described by Yuan et al. [5].

\section{Discussion}

We could not validate the previously published association between the CT/CC genotypes of SNP rs1800470 and a lower risk for radiation-induced lung toxicity (RILT) in a European cohort. Our results imply that the previous contradictory results concerning TGF- $\beta 1$ SNPs and RILT risk cannot only be explained by ethnic differences in genetic background as they did not correspond with the results of the American/Caucasian population [5,6]. During the last decade, multiple studies have reported associations between TGF$\beta 1$ SNPs and radiation toxicity in multiple types of cancer [9-14]. However, a large $(N=1613)$ independent validation study within the Radiogenomics Consortium, the RAPPER study, and several other studies did not succeed in confirming these associations [15-17]. The major limitations of multiple studies seemed to be the small sample size, multiple testing issues and the absence of independent validation, resulting in false positive associations.

In conclusion, to find significant results for the TGF- $\beta 1$ SNPs it appears that a sufficiently large number of patients is necessary, combined with external validation. Our results stress the importance of including corrections for baseline scores. Given the contrasting results obtained for the TGF- $\beta 1$ SNPs so far, no definite role can be formulated for these polymorphisms in radiationinduced toxicity and they should not be used in treatment decision. New insights in the molecular pathology of RILT might help to identify novel specific parameters in the near future [18].

\section{Conflict of interest statement}

None. 
Table 2

Correlation between TGF- $\beta 1$ genotypes and lung toxicity using maximum dyspnea score and delta dyspnea score.

\begin{tabular}{|c|c|c|c|c|c|c|c|}
\hline \multirow[t]{2}{*}{ Genotype } & \multicolumn{3}{|c|}{ Maximum dyspnea score } & \multicolumn{4}{|l|}{ Delta dyspnea score } \\
\hline & $\begin{array}{l}\text { Total no. of } \\
\text { patients }\end{array}$ & $\begin{array}{l}\text { No. max. dyspnea } \\
\text { score } \geqslant 2\end{array}$ & $P^{\mathrm{a}}$ & $\begin{array}{l}\text { No. improve delta dyspnea } \\
\text { score }\end{array}$ & $\begin{array}{l}\text { No. worsen delta dyspnea } \\
\text { score }\end{array}$ & $\begin{array}{l}P \\
3 \\
\text { group }^{\mathrm{a}}\end{array}$ & $\begin{array}{l}P \\
\text { improve }+ \text { stable versus } \\
\text { worsen }^{\text {a }}\end{array}$ \\
\hline \multicolumn{8}{|c|}{ rs1800469: C-509T } \\
\hline $\mathrm{CC}$ & 101 & 31 & & 16 & 34 & & \\
\hline $\mathrm{CT}$ & 95 & 26 & 0.498 & 8 & 27 & 0.338 & 0.629 \\
\hline $\mathrm{TT}$ & 13 & 2 & & 2 & 5 & & \\
\hline $\mathrm{CT}+\mathrm{TT}$ & 108 & 28 & 0.444 & 10 & 32 & 0.208 & 0.531 \\
\hline \multicolumn{8}{|c|}{ rs1800470: T869C } \\
\hline $\mathrm{TT}$ & 113 & 36 & & 18 & 36 & & \\
\hline TC & 75 & 16 & 0.251 & 5 & 22 & 0.288 & 0.744 \\
\hline $\mathrm{CC}$ & 21 & 7 & & 3 & 8 & & \\
\hline $\mathrm{TC}+\mathrm{CC}$ & 96 & 23 & 0.206 & 8 & 30 & 0.219 & 0.925 \\
\hline \multicolumn{8}{|c|}{ rs1800471: G915C } \\
\hline GG & 186 & 49 & & 24 & 59 & & \\
\hline GC & 23 & 10 & 0.085 & 2 & 7 & 0.814 & 0.900 \\
\hline $\mathrm{CC}$ & 0 & 0 & & 0 & 0 & & \\
\hline $\mathrm{GC}+\mathrm{CC}$ & 23 & 10 & 0.085 & 2 & 7 & 0.814 & 0.900 \\
\hline
\end{tabular}

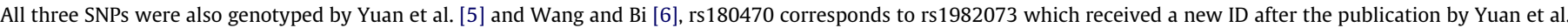

a $\chi^{2}$ test for three (grey) or two (combined) genotypes.

\section{Acknowledgement}

We acknowledge financial support from the CTMM framework (AIRFORCE project), EU 6th and 7th framework program (Artforce and Metoxia program), Interreg (www.eurocat.info), and the Dutch Cancer Society (KWF UM 2011-5020, KWF UM 2009-4454).

\section{References}

[1] De Ruysscher D, Dehing C, Yu S, et al. Dyspnea evolution after high-dose radiotherapy in patients with non-small cell lung cancer. Radiother Oncol 2009;91:353-9.

[2] De Ruysscher D, Houben A, Aerts HJ, et al. Increased (18)F-deoxyglucose uptake in the lung during the first weeks of radiotherapy is correlated with subsequent Radiation-Induced Lung Toxicity (RILT): a prospective pilot study. Radiother Oncol 2009;91:415-20.

[3] McCurdy MR, Wazni MW, Martinez J, McAleer MF, Guerrero T. Exhaled nitric oxide predicts radiation pneumonitis in esophageal and lung cancer patients receiving thoracic radiation. Radiother Oncol 2011;101:443-8.

[4] Lambin P, Petit SF, Aerts HJ. The ESTRO Breur Lecture 2009. From population to voxel-based radiotherapy: exploiting intra-tumour and intra-organ heterogeneity for advanced treatment of non-small cell lung cancer. Radiother Oncol 2010;96:145-52.

[5] Yuan X, Liao Z, Liu Z, et al. Single nucleotide polymorphism at rs1982073:T869C of the TGFbeta 1 gene is associated with the risk of radiation pneumonitis in patients with non-small-cell lung cancer treated with definitive radiotherapy. J Clin Oncol 2009;27:3370-8.

[6] Wang L, Bi N. TGF-beta1 gene polymorphisms for anticipating radiationinduced pneumonitis in non-small-cell lung cancer: different ethnic association. J Clin Oncol 2010;28:e621-2.

[7] van Elmpt W, McDermott L, Nijsten S, Wendling M, Lambin P, Mijnheer B. A literature review of electronic portal imaging for radiotherapy dosimetry. Radiother Oncol 2008;88:289-309.
[8] Kelsey CR, Jackson L, Langdon S, et al. A polymorphism within the promoter of the TGFbeta1 gene is associated with radiation sensitivity using an objective radiologic endpoint. Int J Radiat Oncol Biol Phys 2012;82:e247-55.

[9] Hilbers FS, Boekel NB, van den Broek AJ, et al. Genetic variants in TGFbetaand PAI- 1 as possible risk factors for cardiovascular disease after radiotherapy for breast cancer. Radiother Oncol 2012;102:115-21.

[10] Andreassen CN, Alsner J, Overgaard M, Overgaard J. Prediction of normal tissue radiosensitivity from polymorphisms in candidate genes. Radiother Oncol 2003;69:127-35.

[11] Giotopoulos G, Symonds RP, Foweraker K, et al. The late radiotherapy normal tissue injury phenotypes of telangiectasia, fibrosis and atrophy in breast cancer patients have distinct genotype-dependent causes. $\mathrm{Br} \mathrm{J}$ Cancer 2007;96:1001-7.

[12] Quarmby S, Fakhoury H, Levine E, et al. Association of transforming growth factor beta-1 single nucleotide polymorphisms with radiation-induced damage to normal tissues in breast cancer patients. Int J Radiat Biol 2003;79:137-43.

[13] Andreassen CN, Alsner J, Overgaard J, et al. TGFB1 polymorphisms are associated with risk of late normal tissue complications in the breast after radiotherapy for early breast cancer. Radiother Oncol 2005;75:18-21.

[14] Zhang L, Yang M, Bi N, et al. Association of TGF-beta1 and XPD polymorphisms with severe acute radiation-induced esophageal toxicity in locally advanced lung cancer patients treated with radiotherapy. Radiother Oncol 2010;97:19-25.

[15] Barnett GC, Coles CE, Elliott RM, et al. Independent validation of genes and polymorphisms reported to be associated with radiation toxicity: a prospective analysis study. Lancet Oncol 2012;13:65-77.

[16] Fachal L, Gomez-Caamano A, Sanchez-Garcia M, et al. TGFbeta1 SNPs and radio-induced toxicity in prostate cancer patients. Radiother Oncol 2012;103:206-9.

[17] Martin S, Sydenham M, Haviland J, et al. Test of association between variant tgbeta 1 alleles and late adverse effects of breast radiotherapy. Radiother Oncol 2010;97:15-8.

[18] Cappuccini F, Eldh T, Bruder D, et al. New insights into the molecular pathology of radiation-induced pneumopathy. Radiother Oncol 2011;101:86-92. 